\title{
The Effect of Board Diversity on Real Earnings Management: Empirical Evidence From Jordan
}

\author{
Ahmad Almashaqbeh ${ }^{1}$, Hasnah Shaari ${ }^{1} \&$ Hijattulah Abdul-Jabbar ${ }^{1}$ \\ ${ }^{1}$ Tunku Puteri Intan Safinaz School of Accountancy, Universiti Utara Malaysia, Malaysia \\ Correspondence: Ahmad Almashaqbeh, Tunku Puteri Intan Safinaz School of Accountancy, Universiti Utara \\ Malaysia, Malaysia.
}

Received: April 30, 2019

Accepted: May 30, 2019

Online Published: June 11, 2019

doi:10.5430/ijfr.v10n5p495

URL: https://doi.org/10.5430/ijfr.v10n5p495

\begin{abstract}
This study considers the effect of foreign board members and age diversity on real earnings management (REM), by controlling the firm size, leverage and growth. This study employed quantitative methodology and longitudinal data for non-financial business firms, quoted on the Amman Stock Exchange from 2011 to 2015. Data were analysed using descriptive statistics and Panel Corrected Standard Errors (PCSE) regression. This study found that foreign boards member, age diversity, leverage and growth had negative and significant associations with REM. Based on the results, a firm should appoint young members to the board in addition to older members to pave the way to cross-ideology that can deter REM activities. At least one foreign director should exist within the board of directors because a foreign board member has different qualifications and experiences that may help to deter REM practices.
\end{abstract}

Keywords: age diversity, foreign board member, real earnings management

\section{Introduction}

Board of directors plays their significant role to increase the business performance, through the development of strategic objectives and working for the mission and vision statements (Fama \& Jensen, 1983; Johnson, Schnatterly, \& Hill, 2013; Chouaibi, Harres, \& Brahim, 2016). Elected by a company's shareholders, the board of directors are responsible for the financial and strategic decisions in the business firms (Alam, Chen, Ciccotello, \& Ryan, 2014). In this regard, Shawtari, Mohammed, Abdul Rashid, and Ayedh (2017) explained that the composition of the board is an important mechanism to guarantee board effectiveness. The important strategic role of BOD is to work for the financial reporting and delivering accounting information to its users for which earnings management cannot be overlooked.

In the overall structure of corporate governance, diversity in the board is the core issue. Generally, diversity has been studied through various categories such as the age, the nationality, the education, and the gender of board members (Hambrick \& Mason, 1984; Johnson et al., 2013; Post \& Byron, 2015). Diversity has been found to enhance both the innovation and the creativity of the boardroom ( Miller \& Del Carmen Triana, 2009; Galia \& Zenou, 2012). It also works to serve as per the wishes of their customers and employees (Brammer, Grosvold, \& Rayton, 2007). Each of these board diversity categories affects firm-level results through cognition and the recognition of social identity (Kagzi \& Guha, 2018). Notably, the concept of board diversity considers the significant phenomenon from the context of literature (Hisham Farag \& Mallin, 2016; Rao \& Tilt, 2016). This idea has put significant attention to the discussion of board diversity in front of various scholars (Hillman, 2015; Mahadeo, Soobaroyen, \& Hanuman, 2012).

During the past decades, scholars have empirically examined the role of the demographic attributes of the board of director, and they have argued that such attributes are related to organizational results (Chapple \& Humphrey, 2014; Farag \& Mallin, 2017; Chang, 2017). Most related research considers the link between board attributes and quality of earnings from the perspective of accrual-based earning management (AEM) or financial statement restatements (Kyaw, Olugbode, \& Petracci, 2015; Hoang, Abeysekera, \& Ma, 2017). However, how board diversity affects activities of earnings management are rarely studied. Hence, investigating how diversity in boardroom influences real earnings management is essential. The current study, therefore, fills this gap by investigating how board diversity effect on earnings management of the business firm from the REM perspective. 
In the Jordanian context, several empirical studies, reports, and official statements have indicated that the listed companies, specifically non-financial firms, have been obviously practicing earnings management activities. These practices have been attributed to the drawbacks of the corporate governance in force and also to the insufficiency of accounting legislation. Many empirical studies have confirmed the presence of the phenomenon of earnings management in Jordanian companies, for example, Alhajaya and Aldebaee (2011), Al-Mustafa (2012), Almomani, (2016), and Alhadab (2018). These researchers have concluded that those firms which are listed in Amman Stock Exchange (ASE) are still practising earnings management activities, even post implementation of the mandatory IFRS. In addition, Al-ghazzawi and Alsoboa (2016) indicated that up to 50\% of Jordanian companies practised earnings management from 2005 to 2013. Other studies in Jordan have indicated that the earnings management issue has caused the collapse of many Jordanian companies (Al-Sartawi, Hamdan, \& Abu Ijela, 2013; Alomari, 2015; Cossiga, 2018).

Enomoto, Kimura, and Yamaguchi (2015) conducted a study for both real and accrual-based earnings management practices for 39 countries. Figure 1 shows the score of real earnings management practices for many countries, which shows that Jordan is one of the most active countries in practicing real earnings management or REM.

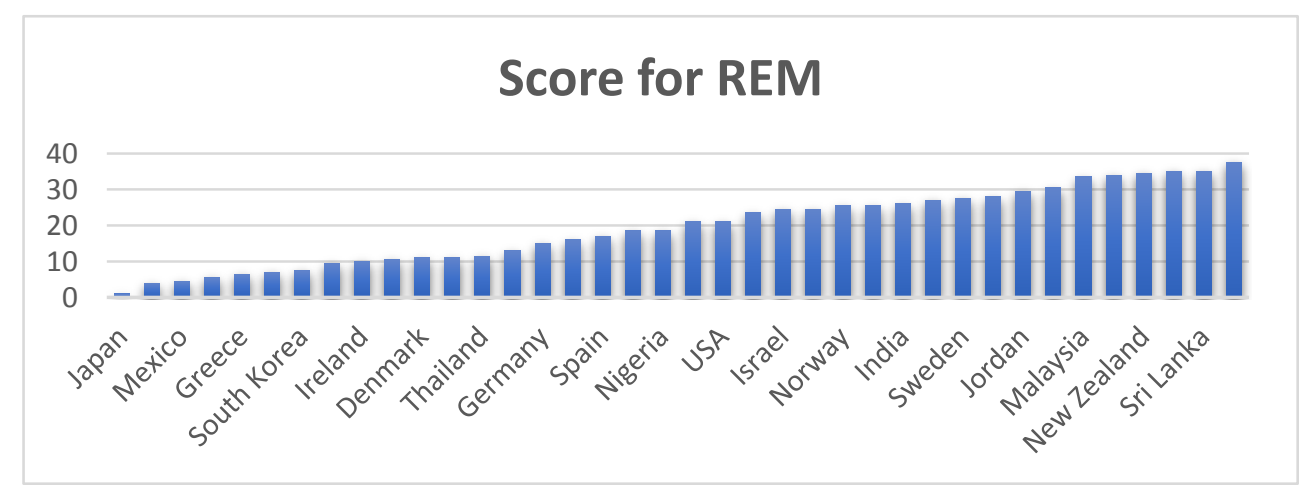

Figure 1. REM scores for 39 countuies

Source: Enomoto, Kimura, and Yamaguch (2015)

The present study contributes to literature through diversity in the board and related research in several ways. At first, it covers the gap in the literature while exploring the relationship between board diversity and REM. The reason is that earlier studies have focused on the board diversity and firm performance merely (Carter, Simkins, Souza, \& Simpson, 2007; Miller \& Del Carmen Triana, 2009; Shehata, Salhin, \& El-Helaly, 2017), firm value (Carter, Simkins, \& Simpson, 2003), social responsibility (Ibrahim \& Hanefah, 2016; Min,2018), earnings quality ( Dagustani,et.al 2016; Hoang et al., 2017) and accrual-based earnings management (Hooghiemstra \& Hermes, 2016; Du, Jian, \& Lai, 2017). However, studies on the relationship between age diversity and foreign board and REM are rarely studied.

The second contribution can be reviewed from the context of response to call Du et al. (2017) who recommended reinvestigating the relationship between foreign members serving on the board and other patterns of earnings manipulation except (accrual-based). They suggest that future studies consider this relationship in another context (except China) taking into consideration the differences in cultural factors among different countries, formal institutions, and marketization. Further, this study comes responds to calls from recent studies to take into consideration the age diversity of the board and its effects on performance, earnings quality and earnings management (Bae \& Skaggs, 2017; Xu, Zhang, \& Chen, 2017). Therefore, this study highlights the diversity of the board of directors that play a significant role in mitigating earnings management practices, i.e. the effect of board diversity on real earnings management.

The rest of the paper is organized as follows. Next section provides a comprehensive review of the literature. Section three explains the hypotheses of the study. Section four provides an overview of the method being used. Section five illustrates the results of the current study and its explanations. The last section provides the conclusions of the study. 


\section{Literature Review}

\subsection{Real Earnings Management}

For some personal purposes, business managers can mislead the users of financial information through AEM and REM because of some financial benefits (Roychowdhury, 2006; Cohen, Mashruwala, \& Zach, 2010; Wongsunwai, 2013). Besides, it is also noticed that business managers are more likely towards the usage of REM, comparatively to AEM. However, usage of REM is found to be highly costly. In addition, with the approval of Sarbanes-Oxley Act Of 2002 (SOX) in USA, managers tend to engage themselves in REM comparatively to the false AEM, because REM gets a low level of scrutiny from the regulators and auditors (Cohen, Dey, \& Lys, 2008; Francis, Hasan, \& Li, 2016).

Ewert and Wagenhofer (2005) defined REM as a changing in the timing or restructuring of transactions related to financial events. REM may, therefore, mean that the manager deviates from an otherwise ideal scheme of actions merely to influence earnings resulting in the imposition of actual costs to the company. Moreover, Cohen and Zarowin (2010) defined REM as the managerial procedures that deviate from normal transaction activities. However, the best definition of REM is presented by Roychowdhury (2006) who calls it as such "management actions that deviate from normal business practices, undertaken with the primary objective of meeting certain earnings" (p. 336). In addition, Roychowdhury (2006) also documents that REM may also mean the violation of normal operational activities, aim to misguide stakeholders and seek the approval of certain financial reporting objectives. Depending on this definition certain techniques can be used to manipulate earnings by real activities, for instance, discretionary expenditures reductions and announcing a major percentage of discounts on sales optimally under certain economic circumstances.

By practising REM activities, managers realize that they must sacrifice future cash flows to fulfil short-lived benchmarks. However, because REM involves managerial decisions related to operational strategies and investments, REM becomes more difficult to detect and avoid its impacts on cash flows (Kothari, Mizik, \& Roychowdhury, 2012; Chidoko and Mashavira, 2014; Salvioni and Gennari, 2014; Razek, 2014; Eshiet, 2017; Mejdoub and Arab, 2017; Oitsile., Galebotswe and Sekwati, 2018; Chang'ach, 2018). Previous research indicates that non-fraudulent AEM is less harmful to current stockholders than REM because it does not weaken a company's cash flows (Roychowdhury, 2006; Cohen \& Zarowin, 2010; Kothari et al., 2012; Ali, et.al. 2016; Omodero and Ogbonnaya, 2018).

\subsection{Board Nationality Diversity}

Board nationality diversity defined as the existence of at least one holding member foreign-nationality within the board of director (Staples, 2007). Various governance instructions focus on the hiring of individuals from various nationalities in board of director for their stakeholders, employees and customers. This is due the hiring of foreign directors is seen to enhance the decision process and its quality for the board (Ibrahim \& Hanefah, 2016). In addition, Ruigrok, Peck, and Tacheva (2007) suggest that foreign directors bring with them diverse ideas and viewpoints, such as religion, language, culture life, experiences, norms and behaviour of the company or state, which, in turn, improve the decision-making operation. The assumption may be made that foreign board membership is a primary element of a corporate governance framework that defines the value of companies and the distribution of resources amongst different stakeholders (Oxelheim \& Randoy, 2003; Romli and Ismail, 2014; Ekpung, 2014; Sarwar and Mubarik, 2014 ; Okon and Monday, 2017; Kimengsi and Gwan, 2017; Bollazzi and Risalvato, 2018).

Foreign directors can impact firm value through their monitoring and advise actions. In this regard, Miletkov, Poulsen, and Wintoki, (2017) indicate that foreign directors represent a unique type of director, and their diverse experiences and backgrounds can extend their companies' strategic alternatives. They found a direct association between foreign directors and performance of the firm, especially in those states having poor financial institutions and when that director belongs to a country with more robust legal institutions than a company's home country. The assumption under agency issue suggests that a variety of expertise on the board of director enhances performance as the board will be more effective in practising its monitoring role. As a result, foreign directors contribute to the diversity of boards (Mori \& Towo, 2017). In this regard, Estélyi and Nisar (2016) suggest that a great possibility exists that companies with a variety of nationalities serving on their boards will have a higher chance of achieving value.

\subsection{Board Age Diversity}

Age variety on the board is a significant attribute of the board of director as explained by (Ferrero-Ferrero, Fernández-Izquierdo, \& Muñoz-Torres, 2015; Ibrahim \& Hanefah, 2016). The age class of directors is considered to be a significant indicator of board diversity (Kang, Cheng, \& Gray, 2007), and board age may be defined as the total ages of all boardroom members serving on the board (Anderson, Mansi, \& Reeb, 2004). Existing psychology and 
accounting literature point out a positive association between ethical behaviour and age. In this context, Mudrack (1989) indicates that age is an efficient indicator of ethical behaviour. The author argues that because older people have constant, long exposure to culture, customs and traditions, they are more ethical. Moreover, Carter et al. (2003) suggest that board age diversity and gender composition influence the effectiveness of the monitoring of a firm's and consequently positively impact the financial performance of the corporate. Besides, age diversity mitigates the probability of emotional and harmful conflicts, while convergence in age oftentimes leads to job comparisons which may lead to competition among boardroom members (Pelled, Eisenhardt, \& Xin, 1999). This, in turn, perhaps impacts board functioning and corporate performance.

\section{Hypotheses Development}

\subsection{Board Nationality Diversity and Real Earnings Management}

The presence of a foreign director is often used as a proxy for board nationality diversity. In this regard, there are mixed findings regarding the association between the presence of a foreign member and earnings management. For example, Hooghiemstra, Hermes, Oxelheim, and Randøy (2016) provide evidence indicating that the existence of non-Nordic foreign directors instead of foreigners per se was linked to greater levels of earnings management. Similarly, Firoozi, Magnan, Fortin, and Nicholls (2016) provided evidence that the proportion of foreign members serving on the audit committee has a negative link with the quality of financial reporting.

Based on the notion of agency cost, the key obligation of board members is to resolve the conflict between management and stakeholder, as they are highly responsible for the internal control of the business (Fama \& Jensen, 1983), as the board can either appoint or dismiss managers and has the power to set executive compensations. Consequently, the argument has been made that board diversity also improves the monitoring role of directors for many reasons. First, diversity of board can enhance the quality of boardroom decision-making and, therefore, restrain misstatement financial reports early on (Makhija \& Stewart, 2002; Du et al., 2017). Second, board diversity enhances the independence of the boardroom and thus provides efficient control and monitoring of a firm's actions. Previous research has found that earnings management and board independence are negatively associated with each other (Klein, 2002; Bowen, Rajgopal, \& Venkatachalam, 2008).

Based on the above discussion, the prediction can be made that the foreign members serving on a board enhance board independence and improve decision-making ability. Consequently, based on the earlier findings and agency theory, the nationality diversity of the board plays an essential part in monitoring management and reducing earnings management. Accordingly, the following hypothesis is posited:

$\mathrm{H}_{1}$ : There is a negative relationship between foreign board members and real earnings management.

\subsection{Board Age Diversity and Real Earnings Management}

The previous empirical research rarely examined the association between earnings management and board age diversity. But it is possible to infer the significance of the relationship through studies conducted on the relationship between corporate performance and the diversity of the board. In this regard, several studies have an inverse linkage between corporate performance and diversity in the age of directors (Ali, Ng, \& Kulik, 2014; Shehata et al., 2017). $\mathrm{Li}$, Chu, Lam, and Liao (2011) found a positive relationship between board diversity and performance. Furthermore, Ercan (2017) found an insignificant relationship between the age diversity of board members and firm performance. Some authors have concluded that the age of board member has no effect on the financial restatement. However, by using Chinese corporate data from 2010 to 2013, Xu et al. (2017) found that board age was negatively associated with the firm financial fraud. Additionally, authors like Huang, Rose-Green, and Lee (2012) and Davidson, Xie, Xu and Ning (2007) indicate a significantly negative association between earnings management and age of board members. Finally, Hoang et al. (2017) concluded that boards diversity including age diversity was not associated with earnings quality.

From a theoretical view, the relationship between board diversity and earnings management can be interpreted by the agency theory, which assumes that board diversity rises board independence (Carter et al., 2003; Carter et al., 2007). And this, in turn, leads to enhancing the strength of boardroom monitoring (Hong et al., 2017). Further, from Shleifer and Vishny (1997) indicated that CEO's maybe require independent oversight. In this case, board diversity and the subsequent conflict that is deemed to happen with a diverse set dynamic probably usually has a positive influence on the supervising function and could be one of the mechanisms used to reduce potential agency problems (Erhardt et al., 2003; Rismayadi \& Maemunah 2018).

More independence of the board lead to better monitoring and controlling of management's actions, which leads to the mitigation of the opportunistic behaviour of managers, and, thus, curbs earnings management practices. Indeed, 
Bae and Skaggs (2017) investigated further of such relationships. The current study contributes to the literature by exploring the following hypothesis:

$\mathrm{H}_{2}$ : There is a negative relationship between board age diversity and real earnings management.

\subsection{Control Variables}

Several control variables based on the literature were included to isolate the effects of this study's test variables on REM. In this regard, the current study also considered the effect of three control variables, namely, firm size, growth and leverage.

Most research conducted on earnings management has used firm size as a control variable. The size of a firm is a good indicator to determine whether a firm must engage in earnings management activities. Watts and Zimmerman, (1978) have emphasised the fall in systematic risk in a large firm and have asserted that as government interference costs (political costs) increase, the large firms grab the attention of all internal and external related parties. Many prior studies utilize firm size as a control variable (Kim \& Sohn, 2013; Francis, Hasan, \& Li, 2016b).

Defond and Jiambalvo (1994) indicate the fact that the presence of debt explains the level of leverage in the business over time. Hence, Jeliek (2007) and Zamri et al. (2013) asserted that increased leverage is related to a lowering in earnings management practices. Following several studies, the current study also uses leverage as a control variable (Sweeney, 1994; Burgstahler, Hail \& Leuz, 2006; Jiang, Zhu \& Huang, 2013).

The growth of the company and its value choice equals the current value of all its actual choices to create future investments (Myers, 1977). Roychowdhury (2006) pointed out that REM systematically differs with growth chances various studies have indicated the fact the negative growth trends can be avoided through the proper level of earnings management in the business.

\section{Methodology}

\subsection{Population and Sampling}

The current study used data from all non-financial companies in Jordan which are listed on the Amman Stock Exchange (ASE) during the period of the current study from 2011 to 2015. The number of all non-financial companies at the end of 2015 was 113 companies, which included 64 industrial sector companies and 49 services sector companies. Note that the companies which were delisted from ASE during the study period were excluded; also, the companies that were newly listed on ASE during the study period were excluded. Thus, the final number of the sample was 101 companies (505 observations), including 57 industrial sector companies and 44 service sector companies.

\subsection{Data Collection}

The secondary data is collected from the annual reports of selected firms. The annual reports were downloaded from the website of Amman Stock Exchange and from the private websites of firms, over the period of 2011 to 2015. The main reason behind the selection of this period for this study was to take into consideration the new Jordanian corporate governance code that has been issued, effective since 2010. This study used correlated panels corrected standard errors method to estimate the regression, where estimation after pooled ordinary least square (OLS) failed to meet the required standard (Beck \& Katz, 1995).

\subsection{Model Specification and Multiple Regressions}

As per the view of Roychowdhury (2006), the concept of earnings management can be explained as a "management actions that deviate from normal real business practices, undertaken with the primary objective of meeting certain earnings" (p. 336). The regression model used to test the relationship between the independent variables (i.e., board age diversity and board nationality diversity) and real earnings management is as follows:

REM $=\beta_{0}+\beta_{1}$ FORBOD $+\beta_{2}$ BODAGDIV $+\beta_{3}$ FSIZE $+\beta_{4}$ GROWTH $+\beta_{5}$ LEVAGE $+\mathrm{e}$.

Where REM =real earnings management, FORBOD $=$ foreign board (Non-Jordanian). BODAGDIV = board age diversity, FSIZE = Firm size, LEVAGE = leverage, GROWTH $=$ growth opportunities, $\mathrm{e}=$ error term

Panel corrected standard error (PCSE) method were adopted to remedy any disturbances resulting from heteroskedasticity and serial correlation, thereby generating unbiased and consistent estimates of parameters. Indeed, Beck and Katz (1995) recommend that, although PCSE gives more accurate estimates than feasible generalized least squares FGLS, either FGLS or PCSE is more efficient than OLS to estimate complicated panel error structures. 


\subsection{Variable Measurements}

The previous studies on management of earnings, as per the model of Dechow, Kothari, and Watts (1998) and modified by Roychowdhury (2006), thereby, later studies have modified models based on Roychowdhury (2006) to measure real earnings management. Notably, authors like Roychowdhury (2006) have more focus on the concept of earnings management in the field of corporate finance and related literature.

This current study uses the Cohen et al. (2008) model, which has three proxies for real earnings management, and they are: 1) abnormal discretionary expenditures, 2) abnormal cost of production and 3) abnormal cash flow of cash from operations.

Every proxy is captured by using an independent cross-sectional regression as follows.

$$
\begin{gathered}
\text { DISX }_{\mathrm{t}} / \mathrm{TA}_{\mathrm{t}-1}=\mathrm{a}_{0}+\left(1 / \mathrm{TA}_{\mathrm{t}-1}\right)+\mathrm{a}_{1}\left(\text { SALES }_{\mathrm{t}-1} / \mathrm{TA}_{\mathrm{t}-1}\right)+\varepsilon_{\mathrm{t}} \\
\text { PROD }_{\mathrm{t}} / \mathrm{TA}_{\mathrm{t}-1}=\mathrm{a}_{0+}\left(1 / \mathrm{TA}_{\mathrm{t}-1}\right)+\mathrm{a}_{1}\left(\mathrm{SALES}_{\mathrm{t}} / \mathrm{TA}_{\mathrm{t}-1}\right)+\mathrm{a}_{2}\left(\Delta \text { SALES }_{\mathrm{t}} / \mathrm{TA}_{\mathrm{t}-1}\right)+\mathrm{a}_{3}\left(\Delta \mathrm{SALES}_{\mathrm{t}-1} / \mathrm{TA}_{\mathrm{t}-1}\right)+\varepsilon_{\mathrm{t}} \\
\text { CFO }_{\mathrm{t}} / \mathrm{TA}_{\mathrm{t}-1}=\mathrm{a}_{0}+\left(1 / \mathrm{TA}_{\mathrm{t}-1}\right)+\mathrm{a}_{1}\left(\text { SALES }_{\mathrm{t}} / \mathrm{TA}_{\mathrm{t}-1}\right)+\mathrm{a}_{2}\left(\Delta \text { SALES }_{\mathrm{t}} / \mathrm{TA}_{\mathrm{t}-1}\right)+\varepsilon_{\mathrm{t}}
\end{gathered}
$$

Note that all these equations are to calculate normal PROD, CFO and DISEXP, Where: $\mathrm{CFO}_{\mathrm{t}}$ : current cash flow from operation, PROD $t$ : the cost of production, and DISEXP: discretionary expenses. St: the sales in year t. $\triangle S A L E S$ ${ }_{t}:\left(\right.$ SALES $\left._{t}-S A L E S t_{-1}\right)$ change in current sales from t-1 to t. SALES $t_{-1}$ : sales in year t-1. $\triangle S A L E S_{t-1}$ : change in sales, $T A_{t-1}$ : is the total asset by the end of the year as expressed through $\mathrm{t}-1$.

Abnormal levels of production cost (REM PRODt) as measured as the residuals of equation (2) while the beyond the normal level of expenditures in the business $\left(\mathrm{REM}_{\mathrm{DIXEPt}}\right)$ and operating cash flows for the business $\left(\mathrm{REM}_{\mathrm{CFOt}}\right)$ are measured under the title of equations (1) and (3) multiplied by -1 . REMt is the sum of REM PRODt $_{\text {, }}$ REM $_{\text {DIXEPt }}$ and REM $_{\text {CFOt. }}$

$$
\mathrm{REM}=\mathrm{CFO} *(-1)+\operatorname{DISEXP} *(-1)+\mathrm{PROD}
$$

The measurement of independent and control predictors is shown in the table below.

Table 1. Measurement of the key variables of the study

\begin{tabular}{ll}
\hline Variables & Operationalization \\
\hline Independent Variables & \\
\hline $\begin{array}{l}\text { Foreign board member } \\
\text { (FORBOD) }\end{array}$ & $\begin{array}{l}\text { Dummy variable equals to 1 if there is at least one foreign director on the board of } \\
\text { directors and 0 if otherwise (Choi, Park, \& Yoo, 2007; Estélyi \& Nisar, 2016; Du et al., } \\
\text { 2017). }\end{array}$ \\
\hline $\begin{array}{ll}\text { Board Age Diversity } \\
\text { (BODAGDIV) }\end{array}$ & $\begin{array}{l}\text { The coefficient of variation by considering the standard deviation of the age of board } \\
\text { members with their mean value (Pelled et al., 1999; Ali et al., 2014; Li \& Wahid, 2018). }\end{array}$ \\
\hline Control variables & \\
\hline Firm size (FSIZE) & The natural logarithm of total assets (Kang \& Kim, 2012; Sakaki, Jackson, \& Jory, 2017). \\
\hline $\begin{array}{l}\text { Firm } \\
\text { (GROWTH) }\end{array}$ & Growthet to book value of equity ratio (Wild, 1996; Franz, HassabElnaby, \& Lobo, 2014). \\
\hline Leverage (LEVAGE) & Total debt divided by total assets (Osma, 2008; Anagnostopoulou \& Tsekrekos, 2017). \\
\hline
\end{tabular}

\section{Empirical Results}

\subsection{Descriptive Statistics}

Table 2 presents descriptive statistics of the study variable. Table 2 shows the mean values of REM, foreign board, board age diversity, firm size, growth and leverage are $0.0000,0.423,10.495,7.365,1.358$ and 0.348 , respectively. These findings indicate that most of the firms, in Jordan have appointed foreign members on the board. Meanwhile, average firm size is measured through natural logarithm of overall assets has a mean score of 7.365 with the deviation from the mean score of 0.65 . 
Table 2. Descriptive findings of the study

\begin{tabular}{lcccccr}
\hline Variable Names & Mean & \multicolumn{1}{l}{ S.D } & Minimum & Maximum & Skewness & \multicolumn{1}{l}{ Kurtosis } \\
\hline REM & $-1.58 \mathrm{e}-09$ & 0.2236677 & -1.190461 & 0.7601655 & -.9950294 & 5.857979 \\
\hline FORBOD & 0.4237624 & 0.4946436 & 0 & 1 & .3085584 & 1.095208 \\
\hline BODAGDIV & 10.49597 & 4.061588 & 0.3954199 & 22.62742 & .0288369 & 2.541723 \\
\hline FSIZE & 7.365834 & 0.6512111 & 5.671957 & 9.087522 & .2494386 & 3.718070 \\
\hline GROWTH & 1.358303 & 1.045077 & 0.1683436 & 5.295275 & 1.751801 & 6.127226 \\
\hline LEVAGE & 0.3487971 & 24.03941 & -54.0908 & 1.796333 & 1.095621 & 5.805933 \\
\hline
\end{tabular}

\subsection{Correlation Analysis}

The pairwise correlation test was performed and presented in Table 3. Such test indicates the level of association between variables through the correlation matrix, which explains the problem of multicollinearity (high correlation) between them. As per the findings of Gujarati (1995), the problem of higher interdependency between variables exists if the value is greater than .80. In Table 3 , it is observed that there is no issue of high correlation between the variables is below .80 and highest association is 0.03156 between firm size and factor of leverage.

Table 3. Correlation matrix results

\begin{tabular}{|c|c|c|c|c|c|c|}
\hline Variable & REM & FORBOD & BODAGDIV & FSIZE & GROWTH & LEVAGE \\
\hline REM & 1 & & & & & \\
\hline FORBOD & 0.0224 & 1 & & & & \\
\hline BODAGDIV & -0.0858 & -0.1033 & 1 & & & \\
\hline FSIZE & -0.0263 & 0.1523 & 0.0336 & 1 & & \\
\hline GROWTH & -0.3102 & -0.0670 & -0.0182 & 0.0634 & 1 & \\
\hline$L E V A G E$ & 0.1163 & 0.0213 & -0.1270 & 0.3156 & 0.1258 & 1 \\
\hline
\end{tabular}

\subsection{Multicollinearity Test}

The multicollinearity test was done to ensure that no multicollinearity problematicexist, this study considers the value of VIF to check either there is a problem of correlation or not. Table 4 show the result of multicollinearity test, the mean VIF is less than 5 demonstrating that there is no problem of multicollinearity between variables.

Table 4. Multicollinearity test

\begin{tabular}{lll}
\hline Variable & VIF & $\mathbf{1 / V I F}$ \\
\hline FORBOD & 1.04 & 0.957484 \\
\hline BODAGDIV & 1.04 & 0.964714 \\
\hline FSIZE & 1.15 & 0.869935 \\
\hline GROWTH & 1.02 & 0.977852 \\
\hline LEVAGE & 1.15 & 0.869603 \\
\hline Mean VIF & $\mathbf{1 . 0 8}$ & \\
\hline
\end{tabular}




\subsection{Normality Test}

In order to consider the normality of the data set, kurtosis and skewness values have been examined. As per the findings of Leys, Ley, Klein, Bernard, and Licata, (2013), the normality of the variables can be reviewed if the value of skewness statistics is in the internal of 3.0 either positive or negative. Table 2 explains that no variable is found to deviate from the normal data point as skewness values are in the range. Meanwhile, kurtosis values are also in the range which indicates a normal data set (Kline, 2011).

\subsection{Regression Results}

Multiple regression technique is applied while considering the variables under the title of firm age, foreign board members, leverage and growth of the business to examine the developed hypotheses. Findings are presented in Table 5 , and overall variation in the dependent variable is found to be 24.66 percent in REM as explained through adjusted $\mathrm{R}$-square. This indicates that remaining variation is due to some other factors which are not added in the model.

Table 5. Regression results $(\mathrm{n}=505)$

\begin{tabular}{llcc}
\hline Variable & Coef. & t-value & Prob. Value \\
\hline FORBOD & -0.0474408 & -1.980 & $* * 0.047$ \\
\hline BODAGDIV & -0.0056985 & -4.40 & $* * * 0.000$ \\
\hline FSIZE & -.01616710 & -0.89 & 0.371 \\
\hline GROWTH & -.06847750 & -7.91 & $* * * 0.000$ \\
\hline LEVAGE & 0.2154585 & 7.29 & $* * * 0.000$ \\
\hline $\mathrm{R}^{2}$ & 0.2466 & & \\
Prob > chi2 & 0.000 & & \\
\hline
\end{tabular}

Note: $* * *, * *, *$ indicates level of significance at $1 \%, 5 \%, 10 \%$ percent.

\section{Discussion and Conclusion}

The objective of the study is to explore the link among key factors of board diversity (foreign board and age), and REM of the Jordan listed non-financial companies during 2011-2015. The findings under regression analysis are displayed in Table 5. Foreign board (FORBOD) has its significant and negative influence on REM $(\mathrm{t}=-1.980$, $\mathrm{p}<0.05$ ). This result is in favour of the first hypothesis that inverse relationship exists between foreign board and REM. This negative sign indicates that the REM of a specific company decreases when the board of directors includes foreign members. The presented findings are symmetrical to the Du et al., (2017). Likewise, Miletkov et al. (2017) have found a significant but positive relationship between firm performance and foreign directors, especially in nations with low-quality statutory institutions, and when such a director hails from a state with greater quality statutory institutions than the company's host country (Ahmed, Majid \& Zin, 2016; Ali \& Haseeb, 2019; Haseeb, Abidin, Hye, \& Hartani, 2018; Haseeb., 2019; Suryanto, Haseeb, \& Hartani, 2018).

Regarding age diversity of the board (BODAGDIV), the result indicated that director age factor has significant but negative influence on REM $(\mathrm{t}=-4.40, \mathrm{p}<0.01)$. Thus, the second hypothesis $\left(\mathrm{H}_{2}\right)$ was supported, which predicted a negative relationship between the age diversity of the board and REM. This result shows that the increase of age diversity in the boardroom, lead to an increase in the monitoring role of the board, thereby decreasing the practice of REM. This finding is symmetrical to Mahadeo et al. (2012) who found that factor of diversity in the age has positively influenced short-lived performance. Similarly, Li et al. (2011) found a direct association between the financial performance of the organization and diversity in the age of directors.

With respect to control variables, the findings showed that firm size (FSIZE) had a negative but insignificant effect on REM (-0.89). This result is consistent with Llukani, (2013) Elghuweel, Ntim, Opong, and Avison, (2016), and Alexander (2017).

Regarding growth, the findings illustrated that growth has a negative and significant effect on REM $(t=-7.91 . p$ > 0.05). In this regard Nagar (2002) asserts that firms avoid negative growth trends as their rewards usually rely on achieving specific performance thresholds. This can be demonstrated with the fact that companies may be less like to 
utilize real economic procedures to manage earnings because these procedures harm a corporate's competitive edge in the long-term and discourage its growth possibilities. This result is in line with Gunny (2010), whose study found that companies with high growth average were less inclined to engage in real earnings management activities. Additionally, leverage had a positive and significate effect on REM $\left(t_{=} 7.29 \mathrm{p}<0.01\right)$. This result aligned with Vakilifard and Mortazavi (2016) and Anagnostopoulou and Tsekrekos (2017), who found that the relationship between leverage and real earnings management was significant and positive. In sum, although real earnings management is detrimental to a firm's long-term growth, real earnings management remains a widespread behaviour among managers seeking to meet short-term earnings thresholds.

The findings of this current study should be of great interest to regulators and shareholders. The findings indicate that the age diversity in the boardroom can deter costly REM, whilst the existence of foreign members who are present in the board has their significant relationship with REM. However, this research is limited to the region of Jordan with a little size of the sample. Future research should test the arguments and conclusions of this study in different contexts as knowledge of the interactions of the effects of different board compositions remains limited. Better research along with improved literature is much needed for the effects of various metrics about diversity in the board on earnings management, especially in emerging markets.

\section{References}

Ahmed, U., Majid, A. H. A., \& Zin, M. L. M. (2016). HR Moderating HR: Critical link between Developmental HR Practices and work engagement in a Moderated Model. Management Review: An International Journal, 11(2), 4.

Alam, Z. S., Chen, M. A., Ciccotello, C. S., \& Ryan, H. E. (2014). Does the location of directors matter? Information acquisition and board decisions. Journal of Financial and Quantitative Analysis, 49(1), 131-164. https://doi.org/10.1017/S002210901400012X

Alexander, N. (2017). Factors affecting earnings management in the Indonesian stock exchange. Journal of Finance and Banking Review, 2(2), 8-14.

Alhadab, M. M. (2018). Real and accrual earnings management around initial public offerings in Jordan. International Business Research, 11(1), 204-216. https://doi.org/10.5539/ibr.v11n1p204

Ali, A., \& Haseeb, M. (2019). Radio frequency identification (RFID) technology as a strategic tool towards higher performance of supply chain operations in textile and apparel industry of Malaysia. Uncertain Supply Chain Management, 7(2), 215-226. https://doi.org/10.5267/j.uscm.2018.10.004

Ali, K., Khan, Z., Khan, N., Alsubaie, A. H. I., Subhan, F., \& Kanadil, M. (2016). Performance Evaluation of UK Acquiring Companies in the Pre and Post-Acquisitions Periods. Asian Journal of Economics and Empirical Research, 3(2), 130-138. https://doi.org/10.20448/journal.501/2016.3.2/501.2.130.138

Ali, M., Ng, Y. L., \& Kulik, C. T. (2014). Board age and gender diversity: a test of competing linear and curvilinear predictions. Journal of Business Ethics, 125(3), 497-512. https://doi.org/10.1007/s10551-013-1930-9

Anagnostopoulou, S. C., \& Tsekrekos, A. E. (2017). The effect of financial leverage on real and accrual-based earnings management. Accounting and Business Research, 47(2), 191-236. https://doi.org/10.1080/00014788.2016.1204217

Anderson, R. C., Mansi, S. A., \& Reeb, D. M. (2004). Board characteristics, accounting report integrity, and the cost of debt. Journal of Accounting and Economics, 37(3), 315-342. https://doi.org/10.1016/j.jacceco.2004.01.004

Bae, K. B., \& Skaggs, S. (2017). The impact of gender diversity on performance: The moderating role of industry, alliance network, and family-friendly policies-Evidence from Korea. Journal of Management \& Organization, 1-18. https://doi.org/10.1017/jmo.2017.45

Bartov, E. (1993). The timing of asset sales and earnings manipulation. The Accounting Review, 68(4), 840-855.

Beck, N., \& Katz, J. N. (1995). What to do (and not to do) with time-series cross-section data. American Political Science Review, 89(3), 634-647. https://doi.org/10.2307/2082979

Bollazzi, F., \& Risalvato, G. (2018). Corporate Responsibility and ROA: Evidence from the Italian Stock Exchange. Asian Economic and Financial Review, 8(4), 565-570. https://doi.org/10.18488/journal.aefr.2018.84.565.570

Bowen, R. M., Rajgopal, S., \& Venkatachalam, M. (2008). Accounting discretion, corporate governance, and firm performance. Contemporary Accounting Research, 25(2), 351-405. https://doi.org/10.1506/car.25.2.3

Brammer, S., Grosvold, J., \& Rayton, B. (2007). Board diversity in the UK and Norway: An exploratory analysis. Business Ethics: A European Review, 16(4), 344-357. https://doi.org/10.1111/j.1467-8608.2007.00508.x 
Burgstahler, D. C., Hail, L., \& Leuz, C. (2006). The importance of reporting incentives: Earnings management in European private and public firms. The Accounting Review, 81(5), 983-1016. https://doi.org/10.2308/accr.2006.81.5.983

Carter, D. A., Simkins, B. J., \& Simpson, W. G. (2003). Corporate governance, board diversity, and firm value. The Financial Review, 38(1), 33-53. https://doi.org/10.1111/1540-6288.00034

Carter, D. A., Simkins, B. J., Souza, F. D., \& Simpson, W. G. (2007). The diversity of corporate board committees and firm financial performance. https://doi.org/10.2139/ssrn.9727633

Chang, P. (2017). The Importance Performance Analysis of Taiwan tourism mobile marketing. Journal of Tourism Management Research, 4(1), 12-16. https://doi.org/10.18488/journal.31.2017.41.12.16

Chang'ach, J. K. (2018). An Historical Trajectory of the Economic Transformation of the Southern Keiyo Community in Kenya. Global Journal of Social Sciences Studies, 4(2), 52-69. https://doi.org/10.20448/807.4.2.52.69

Chapple, L., \& Humphrey, J. E. (2014). Does board gender diversity have a financial impact? Evidence using stock portfolio performance. Journal of Business Ethics, 122(4), 709-723. https://doi.org/10.1007/s10551-013-1785-0

Chidoko, C., \& Mashavira, N. (2014). An analysis of corporate governance in the banking sector of Zimbabwe. Humanities and Social Sciences Letters, 2(3), 174-180.

Choi, J. T., Park, S. W., \& Yoo, Sean S. (2007). The value of outside directors: Evidence from corporate governance reform in Korea. The Journal of Financial and Quantitative Analysis, 42(4), 941-962. https://doi.org/10.1017/S0022109000003458

Chouaibi, J., Harres, M., \& Brahim, N. B. (2018). The Effect of board director's characteristics on real earnings management: Tunisian-listed firms. Journal of the Knowledge Economy, 9(3), 999-1013. https://doi.org/10.1007/s13132-016-0387-3

Cohen, D. A., \& Zarowin, P. (2010). Accrual-based and real earnings management activities around seasoned equity offerings. Accounting and Economic, 50(1), 2-19. https://doi.org/10.1016/j.jacceco.2010.01.002

Cohen, D. A., Dey, A., \& Lys, T. Z. (2008). Real and accrual-based earnings management in the pre-and post-Sarbanes-Oxley periods. The Accounting Review, 83(3), $757-787$. https://doi.org/10.2308/accr.2008.83.3.757

Cohen, D., Mashruwala, R., \& Zach, T. (2010). The use of advertising activities to meet earnings benchmarks: Evidence from monthly data. Review of Accounting Studies, 15(4), 808-832. https://doi.org/10.1007/s11142-009-9105-8

Cossiga, G. A. (2018). Signals from the World of Economics. The Price Constant and the Democratic Issue. International Journal of Social and Administrative Sciences, 3(1), 1-21.

Dagustani, D., Buchory, H. A., Satya, M. T., \& Diryana, I. (2016). The Internal Branding Process: Customer Reprofiling and Brand Positioning (Empirical Study on Traditional Snack Food in Bandung-Indonesia). International Journal of Business, Economics and Management, 3(2), 18-30. https://doi.org/10.18488/journal.62/2016.3.2/62.2.18.30

Davidson, W. N., Xie, B., Xu, W., \& Ning, Y. (2007). The influence of executive age, career horizon and incentives on pre-turnover earnings management. Journal of Management and Governance, 11(1), 45-60. https://doi.org/10.1007/s10997-007-9015-8

Dechow, P. M., Kothari, S. P., \& Watts, R. L. (1998). The relation between earnings and cash flows. Journal of Accounting and Economics, 25(2), 133-168. https://doi.org/10.1016/S0165-4101(98)00020-2

Defond, M. L., \& Jiambalvo, J. (1994). Debt covenant violation and manipulation of accruals. Journal of Accounting \& Economics, 17(1), 145-176. https://doi.org/10.1016/0165-4101(94)90008-6

Dimitrov, V., \& Jain, P. C. (2008). The value-relevance of changes in financial leverage beyond growth in assets and GAAP earnings. Journal of Accounting, Auditing \& Finance, 23(2), 191-222. https://doi.org/10.1177/0148558X0802300204

Du, X., Jian, W., \& Lai, S. (2017). Do foreign directors mitigate earnings management? Evidence from China. International Journal of Accounting, 52(2), 142-177. https://doi.org/10.1016/j.intacc.2017.04.002

Ekpung, E. G. (2014). Public infrastructure spending and economic growth in Nigeria: An Error Correction Mechanism (ECM) approach. Journal of Social Economics Research, 1(7), 129-140. 
Elghuweel, M. I., Ntim, C. G., Opong, K. K., \& Avison, L. (2017). Corporate governance, Islamic governance and earnings management in Oman: A new empirical insights from a behavioural theoretical framework. Journal of Accounting in Emerging Economies, 7(2), 190-224. https://doi.org/10.1108/JAEE-09-2015-0064

Enofe, A. O., Lyafekhe, C., \& Eniola, J. O. (2017). Board ethnicity, gender diversity and earnings management: evidence from quoted firms in Nigeria. International Journal of Economics, Commerce and Management, 5(6), 78-90.

Enomoto, M., Kimura, F., \& Yamaguchi, T. (2015). Accrual-based and real earnings management: An international comparison for investor protection. Journal of Contemporary Accounting \& Economics, 11(3), $183-198$. https://doi.org/10.1016/j.jcae.2015.07.001

Ercan, A. Y. (2017). Value in diversity? A quantitative examination of board diversity and financial performance of publicly listed firms in Germany. Retrieved from http://essay.utwente.nl/72752/

Eshiet, U. E. (2017). Implications of Accountants Unethical Behavior and Corporate Failures. International Journal of Business, Economics and Management, 4(4), 82-94. https://doi.org/10.18488/journal.62.2017.44.82.94

Estélyi, K. S., \& Nisar, T. M. (2016). Diverse boards: Why do firms get foreign nationals on their boards?. Journal of Corporate Finance, 39, 174-192. https://doi.org/10.1016/j.jcorpfin.2016.02.006

Ewert, R., \& Wagenhofer, A. (2005). Economic effects of tightening accounting standards to restrict earnings management. The Accounting Review, 80(4), 1101-1124. https://doi.org/10.2308/accr.2005.80.4.1101

Fama, E., \& Jensen, M. C. (1983). Agency problems and residual claims. The Journal of Law \& Economic, 26(2), 327-349. https://doi.org/10.1086/467038

Farag, H., \& Mallin, C. (2016). The relationship between board diversity and firm performance: Evidence from the banking sector in Pakistan. Journal of Business Ethics, 139(2), 333-349. https://doi.org/10.1007/s10551-015-2649-6

Farag, H., \& Mallin, C. (2017, January). Board diversity and financial fragility: Evidence from European banks. International Review of Financial Analysis, 49, 98-112. https://doi.org/10.1016/j.irfa.2016.12.002

Ferrero-Ferrero, I., Fernández-Izquierdo, M. Á., \& Muñoz-Torres, M. J. (2015). Age diversity: An empirical study in the board of directors. Cybernetics and Systems, 46(3-4), 249-270. https://doi.org/10.1080/01969722.2015.1012894

Firoozi, M., Magnan, M., Fortin, S., \& Nicholls, S. (2016). Do foreign directors on audit committees enhance financial reporting quality?. Série Scientifique Scientific Series Montréal, 23, 1-46.

Francis, B., Hasan, I., \& Li, L. (2016). Abnormal real operations, real earnings management, and subsequent crashes in stock prices. Review of Quantitative Finance and Accounting, 46(2), 217-260. https://doi.org/10.1007/s11156-014-0468-y

Franz, D. R., HassabElnaby, H. R., \& Lobo, G. J. (2014). Impact of proximity to debt covenant violation on earnings management. Review of Accounting Studies, 19(1), 473-505. https://doi.org/10.1007/s11142-013-9252-9

Galia, F., \& Zenou, E. (2012). Board composition and forms of innovation: does diversity make a difference?. European J. of International Management, 6(6), 630-650. https://doi.org/10.1504/EJIM.2012.050425

Garven, S. (2015). The effects of board and audit committee characteristics on real earnings management: Do boards and audit committees play a role in its promotion or constraint?. Academy of Accounting and Financial Studies Journal, 19(1), 67-84.

Graham, J. R., Harvey, C. R., \& Rajgopal, S. (2005). The economic implications of corporate financial reporting. Journal of Accounting and Economics, 40(1), 3-73. https://doi.org/10.1016/j.jacceco.2005.01.002

Gunny, K. A. (2010). The relation between earnings management using real activities manipulation and future performance: Evidence from meeting earnings benchmarks. Contemporary Accounting Research, 27(3), 855-888. https://doi.org/10.1111/j.1911-3846.2010.01029.x

Hair, J. F., Black, W. C., Babin, B. J., \& Anderson, R. E. (2010). Multivariate data analysis (7th ed.). Upper Saddle River.

Hambrick, D. C., \& Mason, P. A. (1984). Upper echelons: The organization as a reflection of its top managers. The Academy of Management Review, 9(2), 193-206. https://doi.org/10.5465/AMR.1984.4277628. 
Haseeb, M., Abidin, I. S. Z., Hye, Q. M. A., \& Hartani, N. H. (2018). The Impact of Renewable Energy on Economic Well-Being of Malaysia: Fresh Evidence from Auto Regressive Distributed Lag Bound Testing Approach. International Journal of Energy Economics and Policy, 9(1), 269-275.

Haseeb., H. Z., G. Hartani., N. H., Pahi., M. H., \& Nadeem., H. (2019). Environmental Analysis of the Effect of Population Growth Rate on Supply Chain Performance and Economic Growth of Indonesia. Ekoloji, 28(107).

Hasnan, S., \& Marzuki, H. (2017). Board of directors' characteristics and financial restatement. JMFIR, 14(1), 1-22.

Hillman, A. J. (2015). Board diversity: Beginning to unpeel the onion. Corporate Governance: An International Review, 23(2), 104-107. https://doi.org/10.1111/corg.12090

Hoang, T. C., Abeysekera, I., \& Ma, S. (2017). The effect of board diversity on earnings quality: An empirical study of listed firms in Vietnam. Australian Accounting Review, 27(2), 146-163. https://doi.org/10.1111/auar.12128

Hooghiemstra, R., \& Hermes, N. (2016). The impact of board internationalization on earnings management. https://doi.org/10.2139/ssrn.2714428

Hooghiemstra, R., Hermes, N., Oxelheim, L., \& Randøy, T. (2016). The impact of board internationalization on earnings management. https://doi.org/10.2139/ssrn.27144288

Huang, H. W., Rose-Green, E., \& Lee, C. C. (2012). CEO age and financial reporting quality. Accounting Horizons, 26(4), 725-740. https://doi.org/10.2308/acch-50268

Huang, X., \& Sun, L. (2015, November). Managerial ability and real earnings management. Advances in Accounting, $1-14$.

Ibrahim, A. H., \& Hanefah, M. M. (2016). Board diversity and corporate social responsibility in Jordan. Journal of Financial Reporting and Accounting, 14(2), 279-298. https://doi.org/10.1108/JFRA-06-2015-0065

Jeliek, K. (2007). The effect of leverage increases on earnings management. Journal of Business \& Economic Studies, 13(2), 24-47.

Jiang, F., Zhu, B., \& Huang, J. (2013). CEO's financial experience and earnings management. Journal of Multinational Financial Management, 23(3), 134-145. https://doi.org/10.1016/j.mulfin.2013.03.005

Johnson, S. G., Schnatterly, K., \& Hill, A. D. (2013). Board composition beyond independence: Social capital, human capital, and demographics. Journal of Management, 39(1), 232-262. https://doi.org/10.1177/0149206312463938

Kagzi, M., \& Guha, M. (2018). Board demographic diversity: a review of literature. Journal of Strategy and Management, 11(1), 33-51. https://doi.org/10.1108/JSMA-01-2017-0002

Kang, H., Cheng, M., \& Gray, S. J. (2007). Corporate governance and board composition: Diversity and independence of Australian boards. Corporate Governance, 15(2), 194-207. https://doi.org/10.1111/j.1467-8683.2007.00554.x

Kang, S.-A., \& Kim, Y.-S. (2012). Effect of corporate governance on real activity-based earnings management: Evidence from Korea. Journal of Business Economics and Management, 13(1), 29-52. https://doi.org/10.3846/16111699.2011.620164

Khan, H., Hassan, R., \& Marimuthu, M. (2017). Diversity on Corporate Boards and Firm Performance: An Empirical Evidence from Malaysia. American Journal of Social Sciences and Humanities, 2(1), 1-8. https://doi.org/10.20448/801.21.1.8

Kim, J. B., \& Sohn, B. C. (2013). Real earnings management and cost of capital. Journal of Accounting and Public Policy, 32(6), 518-543. https://doi.org/10.1016/j.jaccpubpol.2013.08.002

Kimengsi, J. N., \& Gwan, S. A. (2017). Reflections on Decentralization, Community Empowerment and Sustainable Development in Cameroon. International Journal of Emerging Trends in Social Sciences, 1(2), 53-60. https://doi.org/10.20448/2001.12.53.60

Klein, A. (2002). Audit committee, board of director characteristics, and earnings management. Journal of Accounting and Economics, 33(3), 375-400. https://doi.org/10.1016/S0165-4101(02)00059-9

Kothari, S. P., Mizik, N., \& Roychowdhury, S. (2012). Managing for the moment: The role of real activity versus accruals earnings management in SEO valuation. https://doi.org/10.2139/ssrn.1982826.

Kyaw, K., Olugbode, M., \& Petracci, B. (2015, August). Does gender diverse board mean less earnings management?. Finance Research Letters, 14, 135-141. https://doi.org/10.1016/j.frl.2015.05.006 
Leys, C., Ley, C., Klein, O., Bernard, P., \& Licata, L. (2013). Detecting outliers: Do not use standard deviation around the mean, use absolute deviation around the median. Journal of Experimental Social Psychology, 49(4), 764-766. https://doi.org/10.1016/j.jesp.2013.03.013

Li, J., Chu, C. W. L., Lam, K. C. K., \& Liao, S. (2011). Age diversity and firm performance in an emerging economy: Implications for cross- $^{-}$cultural human resource management. Human Resource Management, 50(2), 247-270. https://doi.org/10.1002/hrm.20416

Li, N., \& Wahid, A. S. (2018). Director tenure diversity and board monitoring effectiveness. Contemporary Accounting Research, 35(3), 1363-1394. https://doi.org/10.1111/1911-3846.12332

Llukani, T. (2013). Earnings management and firm size: an empirical analyze in Albanian market. European Scientific Journal, 9(16), 135-143.

Mahadeo, J. D., Soobaroyen, T., \& Hanuman, V. O. (2012). Board composition and financial performance: Uncovering the effects of diversity in an emerging economy. Journal of Business Ethics, 105(3), 375-388. https://doi.org/10.1007/s10551-011-0973-z

Makhija, M. V., \& Stewart, A. C. (2002). The effect of national context on perceptions of risk: A comparison of planned versus free-market managers. Journal of International Business Studies, 33(4), 737-756. https://doi.org/10.1057/palgrave.jibs.8491042

Mejdoub, H., \& Arab, M. B. (2017). A Multivariate Analysis for Risk Capital Estimation in Insurance Industry: Vine Copulas. Asian Development Policy Review, 5(2), 100-119. https://doi.org/10.18488/journal.107.2017.52.100.119

Miletkov, M., Poulsen, A., \& Wintoki, M. B. (2017). Foreign independent directors and the quality of legal institutions. Journal of International Business Studies, 48(2), 267-292. https://doi.org/10.1057/s41267-016-0033-0

Miller, T., \& Del Carmen Triana, M. (2009). Demographic diversity in the boardroom: Mediators of the board diversity-firm performance relationship. Journal of Management Studies, 46(5), 755-786. https://doi.org/10.1111/j.1467-6486.2009.00839.x

Min, W. (2018). The Contribution of the Un Information Dissemination Mechanism to the Awareness of Global Issues. International Journal of Asian Social Science, 8(4), 167-172. https://doi.org/10.18488/journal.1.2018.84.167.172

Mori, N., \& Towo, G. (2017). Effects of boards on performance of local and foreign-owned banks in Tanzania. African Journal of Economic and Management Studies, 8(2), 160-171. https://doi.org/10.1108/AJEMS-06-2016-0090

Mudrack, P. E. (1989). Age-related differences in machiavellianism in an adult sample. Psychological Reports, 64(3), 1047-1050. https://doi.org/10.2466/pr0.1989.64.3c.1047

Myers, S. C. (1977). Determinants of corporate borrowing. Journal of Financial Economics, 5(2), 147-175. https://doi.org/10.1016/0304-405X(77)90015-0

Nagar, V. (2002). Delegation and incentive compensation. The Accounting Review, 77(2), 379-395. https://doi.org/10.2308/accr.2002.77.2.379

Oitsile, B., Galebotswe, O., \& Sekwati, L. (2018). Insurance-Economic Growth Nexus: Evidence from Botswana. Asian Economic and Financial Review, 8(6), 843-852. https://doi.org/10.18488/journal.aefr.2018.86.843.852

Okon, E. O., \& Monday, O. I. (2017). Empirical and Evidence-Based Investigation: External Debt, Poverty and Economic Growth Nexus. International Journal of Applied Economics, Finance and Accounting, 1(1), 37-47. https://doi.org/10.33094/8.2017.11.37.47

Omodero, C. O., \& Ogbonnaya, A. K. (2018). Corporate Tax and Profitability of Deposit Money Banks in Nigeria. Journal of Accounting, Business and Finance Research, 3(2), 47-55. https://doi.org/10.20448/2002.32.47.55

Osma, B. G. (2008). Board independence and real earnings management: The case of R\&D expenditure. Corporate Governance: An International Review, 16(2), 116-131. https://doi.org/10.1111/j.1467-8683.2008.00672.x

Oxelheim, L., \& Randoy, T. (2003). The impact of foreign board membership on firm value. Journal of Banking \& Finance, 27(12), 2369-2392. https://doi.org/10.1016/S0378-4266(02)00395-3

Pelled, L. H., Eisenhardt, K. M., \& Xin, K. R. (1999). Exploring the black box: An analysis of work group diversity, conflict and performance. Administrative Science Quarterly, 44(1), 1-28. https://doi.org/10.2307/2667029 
Post, C., \& Byron, K. (2015). Women on boards and firm financial performance: A meta-analysis. Academy of Management Journal, 58(5), 1546-1571. https://doi.org/10.5465/amj.2013.0319

Rao, K., \& Tilt, C. (2016). Board composition and corporate social responsibility: The role of diversity, gender, strategy and decision making. Journal of Business Ethics, 138(2), 327-347. https://doi.org/10.1007/s10551-015-2613-5

Razek, M. A. (2014). The Association Between Corporate Risk Disclosure and Firm Performance in Emerging Country-The Case of Egypt. Journal of Empirical Studies, 1(3), 105-115.

Rismayadi, B., \& Maemunah, M. (2018). Creative Economy to Increase Community Revenue Based on Tourism Object, Medalsari Village, Pangkalan District Karawang Regency. Journal of Accounting, Business and Finance Research, 3(1), 28-35. https://doi.org/10.20448/2002.31.28.35

Romli, A. A. N., \& Ismail, S. (2014). Quality Management Practices towards Customer Satisfaction in Local Authority Public Services Website. International Journal of Public Policy and Administration Research, 1(3), 80-93.

Roychowdhury, S. (2006). Earnings management through real activities manipulation. Journal of Accounting and Economics, 42(3), 335-370. https://doi.org/10.1016/j.jacceco.2006.01.002

Ruigrok, W., Peck, S., \& Tacheva, S. (2007). Nationality and gender diversity on Swiss corporate boards. Corporate Governance, 15(4), 546-557. https://doi.org/10.1111/j.1467-8683.2007.00587.x

Sakaki, H., Jackson, D., \& Jory, S. (2017). Institutional ownership stability and real earnings management. Review of Quantitative Finance and Accounting, 49(1), 227-244. https://doi.org/10.1007/s11156-016-0588-7

Salvioni, D. M., \& Gennari, F. (2014). Corporate Governance, Sustainability and Capital Markets Orientation. International Journal of Management and Sustainability, 3(8), 469-483.

Sarwar, N., \& Mubarik, M. S. (2014). Foreign Direct Investment (FDI) and Employment: A Case of Province of Punjab, Pakistan. The Economics and Finance Letters, 1(4), 59-65.

Shawtari, F. A. M., Mohammed, M. H. S., Abdul Rashid, H. M., \& Ayedh, A. M. (2017). Board characteristics and real performance in Malaysian State-Owned Enterprises (SOEs). International Journal of Productivity and Performance Management, 66(8), 1064-1086. https://doi.org/10.1108/IJPPM-12-2015-0188

Shehata, N., Salhin, A., \& El-Helaly, M. (2017). Board diversity and firm performance: evidence from the U.K. SMEs. Applied Economics, 49(48), 4817-4832. https://doi.org/10.1080/00036846.2017.1293796

Shleifer, A., \& Vishny, R. (1997). A survey of corporate governance. The Journal of Finance, 52(2), 737-783.

Staples, C. L. (2007). Board globalisation in the world's largest TNCs 1993-2005. Corporate Governance, 15(2), 311-321. https://doi.org/10.1111/j.1467-8683.2007.00573.x

Suryanto, T., Haseeb, M., \& Hartani, N. H. (2018). The Correlates of Developing Green Supply Chain Management Practices: Firms Level Analysis in Malaysia. International Journal of Supply Chain Management, 7(5), 316.

Sweeney, A. P. (1994). Debt-covenant violations accounting responses and managers. Journal of Accounting and Economics, 17(3), 281-308. https://doi.org/10.1016/0165-4101(94)90030-2

Vakilifard, H., \& Mortazavi, M. S. (2016). The impact of financial leverage on accrual-based and real earnings management. International Journal of Academic Research in Accounting, Finance and Management Sciences, 6(2), 53-60. https://doi.org/10.6007/IJARAFMS/v6-i2/2039

Watts, R. L., \& Zimmerman, J. (1978). Towards a positive theory of the determination of accounting standards. Accounting Review, 53(1), 112-134.

Wild, J. J. (1996). The audit committee and earnings quality. Journal of Accounting, Auditing and Finance, 11(2), 247-276. https://doi.org/10.1177/0148558X9601100206

Wongsunwai, W. (2013). The effect of external monitoring on accrual-based and real earnings management: Evidence from venture-backed initial public offerings. Contemporary Accounting Research, 30(1), 296-324.

Xu, Y., Zhang, L., \& Chen, H. (2018). Board age and corporate financial fraud: An interactionist view. Long Range Planning, 51(6), 815-830. https://doi.org/10.1016/j.lrp.2017.08.001

Zamri, N., Rahman, R. A., \& Isa, N. S. M. (2013). The impact of leverage on real earnings management. Procedia Economics and Finance, 7(2), 86-95. https://doi.org/10.1016/S2212-5671(13)00222-0

Zhao, Y., Chen, K. H., Zhang, Y., \& Davis, M. (2012). Takeover protection and managerial myopia: Evidence from real earnings management. Journal of Accounting and Public Policy, 31(1), 109-135. 